\title{
Toplam Kalite Yönetimine Askeri Bakış Açısı: Toplam Kalite Liderliği
}

a Atatürk Üniversitesi, Sosyal Bilimler Enstitüsü, İsletme ABD, Erzurum.

${ }^{b}$ Gümüşhane Üniversitesi, İrfan Can Köse Meslek Yüksekokulu, Gümüşhane.

\section{$\ddot{O} z$}

Toplam Kalite Yönetimi (TKY)'nin en önemli getirilerinden biri Toplam Kalite Liderlĭgi (TKL)'dir. Bu konuda son 30 yıldır ciddi çalışmalar yapılmış ve pratikler geliştirilmiştir. Özellikle $A B D$ Deniz Kuvvetleri'nde üretim yapan ve hizmet sağlayan muharebe destek ve muharebe hizmet destek birlikleri lider personelinin eğitimlerinin nüvesini TKL oluşturmaktadır (Ward, 1992). Bu çalışma da TKL kavramı açıklayııı bir metodolojiyle ele alınarak literatürde daha önce yapılan araştırmalar ve bulguları paylaşılmıştır. Daha sonra TKL'nin özellikleri, temel konseptleri ve dört ön şartı askeri bir bakış açısıyla incelenmiştir. Son bölümde, Türk Silahlı Kuvvetleri (TSK) özelinde TKL incelenerek katkı sağlayabileceğgi yönler işaret edilmiştir. Çalışmanın sonucunda TKL anlayıs ve uygulamalarının TSK'da özellikle eğitim birliklerinde, üretim yapan ve hizmet sağlayan birimlerde; yönetim, tam katılım, ekip ruhu, işbirliği ve koordinasyon, maliyetlerin azaltıml, ürün ve hizmet kalitesinin korunarak yükseltilmesi, kazalarm önlenmesi gibi önemli katkılar sağlayabileceğgi tespit edilmiştir.

Anahtar Kelimeler: Liderlik, Askeri Liderlik, Toplam Kalite Yönetimi, Toplam Kalite Liderliği.

\section{Military Perspective towards Total Quality Management: Total Quality Leadership}

\begin{abstract}
One of the most important contribution of Total Quality Management (TQM) is Total Quality Leadership (TQL). In this regard serious efforts have been made and practices been developed in the last 30 years. Especially in The U.S. Navy, TQL is the core of leader trainning of Battle Supporting and Battle Supporting \& Service units, engaged in manufacturing and providing services. In this study, the concept of TKL is examined in a descriptive research methodology and findings of earlier studies in the literature are shared. Then, the characteristics, basic concepts and the four pre-conditions of $T Q L$ are examined/ interpreted from the military perspective. Finally, TQL is examined according to the specific sides of Turkish Armed Forces and contributional aspects are indicated.
\end{abstract}

Keywords: Leadership, Military Lidership, Total Quality Management, Total Quality Leadership.

\section{Gíriș}

Toplam Kalite Yönetimi (TKY); müşterinin ihtiyaçlarını karşılamaya yönelik, müşteri odaklı, üst yönetimin kararlılık, sorumluluk ve liderliğinde, tüm çalışanların katılımı ile çalışanların düşünce ve değerlerine önem verip, yönetime katarak, motivasyonu artıran, eğitim ile birlikte çalışanların daha etkin, verimli ve yetenekli hale gelmelerini sağlayıcı, hedeflere göre yönetimi ve sürekli gelişmeyi sağlayıp bir örgüt kültürü oluşturan ve insana değer veren bir yasam felsefesidir (Yıldırım, 2006). 
Bu çerçevede, imalat ve hizmet sektöründe başlatılan TKY zamanla kamuda da uygulanmaya başlanmıştır. Bunun en önemli sebebi bilgi ve teknoloji çağı olan günümüzde vatandaşların devletten daha kaliteli bir hizmet (sağlık, güvenlik, asayiş, adalet vb.) istemesidir. Dünya'da ABD, İngiltere, Fransa, İsrail gibi ülkelerde kamuda yeniden yapılanmaya gidilmiş ülkemizde de bu kapsamda başarılı sonuçlar alınmıştır (http://www.kalder.org/). Kamuda TKY anlayışının benimsenmesinde Türk Silahlı Kuvvetleri (TSK), Türkiye' de ilk uygulayıcılardan olmuştur.

TKY'nin en önemli getirilerinden biri de TKL'dir. TKY'de liderlik; gerek personelin sürekli eğitimi ve onlara gelişme fırsatının sağlanması sonucunda motivasyonlarının artırması; gerekse müşteri/son kullanıcı memnuniyetinin ön planda olması ile çalışanlara ve insanlara verilen değeri vurgulamaktadır. TKY anlayışı örgütsel amaçları gerçekleştirmede formel kuralları uygulamaktan çok, personeli etkilemeye dayanmaktadır. Bir başka ifade ile TKY örgütte her aşamada "liderliğe" dayanmaktadır (Kayıkçı, 1999).

Karatay (2006) etkileşimci liderlik yaklaşımına değindiği çalışmasında liderliği şu şekilde tanımlamaktadır; "Liderlik, örgütün amaçlarını saptama, etkinlikleri planlama, yapıyı kurma, kaynakları uygun biçimde kullanma, yönetim süreçlerini kontrol etme ve geliştirmedir". Liderlik, bir örgütün amaçlarını gerçekleştirme ya da bu amaçları değiştirmek için yeni bir yapı ve prosedür başlatma olarak tanımlanabilir. Çinli bir filozof liderliği şöyle tarif eder: "insanlara yapmalarını istediğiniz şeyleri yaptırmak için onları bunun kendi fikirleri olduğuna inandırmaktır." Liderlik teknik yeterlilik ile ahlâki karmaşıklığın birleşmesidir (Karatay,2006).

Liderliğe değişik bir açıdan bakan James MacGregor Burns (1978), liderliği, takip edenlerin yapamayacakları şeyleri yaptırabilmek ve onlara istediklerini yaptırmak şeklinde kabul eden tanımlara katılmamış ve şu tanımı yapmıştır. “Liderlik, liderin izleyenleri, hem kendi hem de izleyenlerin değerlerini ve güdülerini (isteklerini, gereksinimlerini, özlem ve beklentilerini) temsil eden belirli amaçlar için eylemde bulunmaya ikna etmesidir". Liderlik salt bir güç gösterisi değildir; izleyenlerin amaç ve gereksinimlerinden soyutlanamaz.

Lider-izleyen ilişkilerinin özü, genel ya da en azından ortak bir amacın gerçekleştirilmesi doğrultusunda, ayrımlı gizil güce ve güdülenme düzeyine sahip bireyler arası etkileşimdir. Dilbert İlkesi'ne göre liderlik, hiçbir net tanımı olmayan soyut bir niteliktir. Aslında iyi ki böyledir. Çünkü lideri izleyenler tanımı net bir şekilde anlamaları durumunda muhtemelen liderini alaşağı ederler. Liderliğe bazı olumsuz yaklaşanlar lideri "Başkalarına kendi menfaati için iş yaptıran kişi”" olarak tanımlar. Görüldüğü üzere, çok sayıda ve değişik hareket noktalarından kaynaklanan araştırmalar farklı liderlik tanımlarının oluşmasına yol açmıştır (Karatay, 2006).

Doğan (2007)'a göre liderlik, liderin örgütsel amaçlara varabilmek için izleyenlerin gönüllü bir şekilde gayret etmelerini sağlayan sosyal etkileşim sürecidir. 
Zel (2006)'de benzer bir tanımla, liderliği, "iletişim sürecinin mevcut bulunduğu bir ortamda, daha önceleri ortaya koyulmuş amaçlara ulaşmak üzere yönlendirilmiş bireylerarası etkileşim süreci" olarak tanımlamıştır.

Şahin ve Temizel (2007) ise liderlik için şu açıklamayı getirmiştir. "Liderlik kişi topluluklarının ve örgütlerin bulunduğu her ortamda ve zamanda var olan bir gerçekliktir. Liderlik, grup faaliyetlerinin merkez noktasıdır. Liderlik grup işbirliğinin bir kutuplaşma noktasıdır. Bu durum, lider ile grup üyeleri arasında bir etkileşim olduğunu arz eder. Çünkü liderlik, kişilerin eylem veya davranışlarını belirli amaçlar doğrultusunda etkileme ve yönlendirme sanatı olarak görülmektedir. Başka bir ifadeyle liderlik, bir grup insanı daha önceden belirlenmiş amaçlar etrafında toplayabilen ve bu amaçların gerçekleşmesi için onları harekete geçirebilen bilgi ve yeteneklerin toplamidir".

Yukarıda ki liderlik tanımlarına bakıldığında genel olarak iki uzlaşma noktası göze çarpmaktadır. Bunlardan ilki, liderliğin bir grup işlevi olmasıdır. Liderlik ancak iki veya daha fazla insan ilişkisi sürecinde söz konusudur. İkinci uzlaşma noktası ise liderliğin bilinçli bir şekilde başkalarının davranışlarını etkileme arayışında olmasıdır.

TSK, dün olduğu gibi bugün de, gerek yurt içinden, gerekse yurt dişından gelecek tehditleri önleyecek şekilde, düşük yoğunluklu çatışmadan, konvansiyonel savaşa kadar, verilecek her türlü göreve her an hazır olmak durumundadır.

TSK personelinin sevk ve idaresi, her yönü ile üstün bir seviyeye getirilmesi, her an muharebe edecekmiş gibi hazırlanması, verilecek her görevde birlik muharebe gücünün etkin bir şekilde kullanılması bir komutanlık/liderlik yeteneğidir. Bu kapsamda liderlik TSK'nın en önemli kuvvet çarpanlarından birisidir.

Askeri liderlik, temel esaslarıyla genel liderlik teorileri ve yaklaşımlarına benzer bir nitelik taşımaktadır. Barış zamanında Silahlı Kuvvetler genellikle iyi bir idarecilik ve yöneticilikle ayakta kalabilirken; savaş zamanında ordu bütün kademelerde yetkin bir liderliğe ihtiyaç duyacaktır. Savaş esnasında taktik ve stratejik seviyede duyulan bu ihtiyaç uzun bir eğitim ve etkili askeri liderler gerektirmektedir.

Askeri liderlik; vazifenin niteliği, tehdit ve çalışma ortamı, çalışanların eğitimi, mevzuat ve hizmet odaklılık gibi unsurlar açısından kendine özgü dinamikler taşımaktadır. Askeri liderlikte; şeref, yurt sevgisi ve vazife bilinci gibi manevi motivasyon kaynakları; maddi motivasyon kaynaklarına göre daha fazla ön plana çıkmaktadır (Sı̆̆rı, 2006).

Mustafa Kemal Atatürk "Zabit ve Kumandan İle Hasbihal" adlı eserinde, Mareşal Goltz'un, "iyi bir ordunun meydana gelmesinde önemli olan türlü araçların en etkilisi, hiç kuşkusuz birliğin başındaki komutanın etkinliğidir." sözüne vurgu yaparak, askeri liderin etkinliğinin önemine dikkat çekmiştir (Atatürk, 1989).

TKL yaklaşımının amacı: Organizasyon çatısı altında ki tüm personeli sadece görev tanımları ve çalışma konuları ile sınırlandırmak yerine, bütünün bir parçası haline getirmek ve "biz" olgusunu aşılamaktır. 
Fikirlerin ortak değerlere ve kurum kültürüne dönüşmesi, TKL çalışmalarının en önemli adımlarından biridir. Bu adım sadece kalite standartlarının oluşturulması ve bu standartların yakalanmasıyla sağlanamaz. Sürekli değişim ve gelişim kapsamında kalite bilincinin, anlayış ve pratiklerinin, organizasyon politika ve değerleriyle uyumlaştırılması bu kapsamda rasyonel bir seçenektir.

Tüm personelin yaptıkları işi sahiplenmesini sağlamak, söylenildiği kadar kolay değildir. Personelin sadece bedenen görev yapan bireylerden, organizasyon için yeni fikirler üreten, görevin ifasına yönelik çaba sarf eden, sorumluluk almaya istekli bireyler haline dönüşmeleri organizasyonun geleceğine ş̧ık tutar.

Bu çalışmanın amacı, TKL'nin anlaşılmasını sağlayarak TSK özelinde TKL'nin katkı sağlayabileceği yönleri işaret etmektir. Bu kapsamda TKL'nin özellikleri, temel konseptleri ve dört ön şartı askeri bir bakış açısıyla incelenmiş ve TKL anlayışının TSK'da uygulanması için Deming'in ünlü 14 noktasında istifade edilerek askeri uzmanlarla bir değerlendirme yapılmıştır.

Çalışmanın birinci bölümünde TKL kavramı açıklayıcı bir metodolojiyle ele alınmış ve literatürde daha önce yapılan araştırmalar ve bulguları paylaşılmıştır. Ayrıca, TKL'nin özellikleri, temel konseptleri ve dört ön şartı askeri bir bakış açısıyla incelenmiştir. İkinci bölümde TKL anlayışının TSK'da uygulanması için Deming'in ünlü 14 noktasını yeniden düzenlenmiş ve liderlik yaklaşımında bir kılavuz olarak sunulmuştur. Deming'in 14 noktalı yönetim felsefesinin TSK açısından sağlayabileceği katkıların işaret edildiği sonuç bölümüyle çalışma tamamlanmıştır.

\section{TOPLAM KALİTE LIDERLİĞí}

TKL; askeri birlik ve kurumlarda organizasyonel ve operasyonel performans1 geliştirme çalışmalarına yönelik olarak ABD Deniz Kuvvetleri'nde yapılan araştırmalar doğrultusunda, 1984 yılından itibaren araştırılmaya ve uygulanmaya başlanmıştır (White ve Colbertston, 1992). Bu çalışmalar Deming'in öncülügünde ve O'nun katkıları sayesinde şekillenmiştir.

TKL'nin “T”si toplamı: Tüm çalışanların katılımını, yapılan işlerin tüm yönlerini, müşterilerin tümünü ve üretilen ürün ve hizmetlerin tümünü kapsar.

"K" S1, kaliteyi, yani müşterilerin bugünkü beklenti ve ihtiyaçlarını tam ve zamanında karşılayıp, onlara teknik üstünlüğü ve kalitesi olan ürün ve hizmetler sunmayı içerir.

"L"si ise, yönetimin her konuda çalışanlara liderlik yapması, çalışanlara örnek model oluşturması ve organizasyon çapında sistem anlayışının yerleştirilmesidir. Toplam kalite anlayışında yapılandırma, istatistiksel süreç kontrolü, kalite çemberleri, sürekli gelişim, müşteri odaklılık ve çalışan odaklılık beraber ele alınmaktadır (Karataş, 2006).

TKL'nin anahtar bir faktörü, ürün ve hizmetlerdeki farklılıkların azaltılması için tüm süreçlerin standartlaştırılmasıdır. Gelişmenin, standardize yöntemlerin içerisinde daha ortaklaşa bir tutumla elde edilebileceğine inanılmaktadır (Jaehn, 2000). 
Deming, Toplam Kalite Liderliği'ni şu şekilde tanımlamıştır. “Organizasyonun tüm temel süreçlerini değerlendirmek ve iyileştirmek için, bugün ve gelecekte, tüm çalışanların bilgilerinin ve kantitatif metotların etkin olarak kullanılmasıdır."

Tanım, TKL'nin "ne" olduğunu (tüm çalışanların bilgilerinin ve kantitatif metotların (özellikle istatistiksel) etkin olarak kullanılması), çabanın "nereye" yöneleceğini (organizasyonun tüm temel süreçleri ve "ne zaman" uygulanacağını ("şimdi ve gelecekte”) açıklamaktadır. "......tüm temel süreçleri” ifadesinde geçen "Temel” kelimesi; TKL'nin öncelikle göreve ilişkin süreçlere yönelik olarak uygulanması gerekliliğini vurgulamak için kullanılmıştır (Houston ve Dockstader, 1997). Bu yaklaşım sayesinde organizasyonun kaynaklarının önemsiz konular için harcanması önlenmiş olacaktır

Deming ayrıca TKL çalışmalarının organizasyon bünyesinde görev yapan tüm personel tarafından doğru anlaşılması için gereken önemi göstererek TKL'nin ana felsefesini açılayıcı bir tanımlama yapmıştır.

“Organizasyonun tüm temel süreçlerini..." Görev performansı ile doğrudan ilgili olan ve organizasyonun ürün ya da hizmetlerini ortaya çıaran faaliyetler "temel süreçler" olarak adlandırılır (Houston ve Dockstader, 1997). Örneğin bir piyade taburu için temel süreçler düşmanın tesirsiz hale getirilmesi veya hedefin ele geçirilmesidir.

$\mathrm{Bu}$ temel süreçler, tek başına görevin başarılmasına yeterli olmayan birtakım muharebe destek ve muharebe hizmet destek faaliyetleriyle desteklenmektedirler. Örneğin; bir topçu bataryası için temel süreçler, atış isteği gelen hedefe atışın yapılması ve hedefin tam isabetle vurulması için gerekli tüm faaliyetlerdir. Bir bakım onarım takımı için temel süreç muharip birliğin ihtiyaç duyduğu tüm araç, silah ve teçhizat bakım ve onarımlarının ivedilikle yapılması için gerekli tüm faaliyetlerdir.

Tüm resme bakıldığında ise ana muharip birliğin faaliyetlerinin temel süreçleri oluşturduğu, diğer muharebe hizmet ve muharebe hizmet destek birliklerinin faaliyetlerinin ise ana görevin ifası için yardımcı süreçler olduğu görülmektedir. Tüm bu faaliyetlerin görev performansına önem dereceleri kadar etki edeceğinden, iyileştirme faaliyetlerinde, yardımcı süreçlerin iyileştirilmesine ikinci derecede önem verilmeli, temel süreçler iyileştirme faaliyetlerinin odak noktasını oluşturmalıdır. Eldeki mevcut kıt kaynakların sonuca en çok etki yapacakları yere harcanması optimal bir seçenek olacaktır.

“...değerlendirmek...” TKL'de ölçüm ve istatistiksel analizler (1) süreçlere ilişkin problemlerin sebeplerini tespit etmek, (2) sistemdeki değişikliklerin etkilerini ölçmek amacıyla kullanılır. Bilimsel yaklaşım, süreçlerde değişiklik yapmadan önce süreç performansının değerlendirilmesi ve anlaşılmasını gerekli kılar.

“...ve iyileştirmek için..." İyileştirme, operasyonel kuvvetlerin idamesini ve zafer kazanmasını sağlayacak temel süreçlere yönlendirilmelidir. TKL'nin gerçek operasyonel görevlerin yönetimde kullanımı göreli olarak sınırlı olsa da, operasyonel kuvvetler TKL'yi barış zamanında görev hazırlığına katkıda bulunacak süreçlerin iyileştirilmesinde etkin bir şekilde kullanabilirler (Houston ve Dockstader, 1997). 
Süreç iyileştirmesi, süreç performansının sebebini oluşturan ya da birinci derecede etkileyen faktörlerin değiştirilmesini içerir. Bu faktörler $3 \mathrm{M}+\dot{\mathrm{I}}$ olarak ifade edilen "malzeme", "metot", "makine" ve "insan" olmak üzere dört temel kategoride gruplanabilir. İyileştirme her seviyede yapılabilecek bir faaliyet olmakla birlikte önemli ve kalıcı kazançlar elde ederek bunların sürdürülebilirliğini sağlayacak temel faktör üst yönetimin katılımıdır. Bir organizasyonda iyileştirme yapılacak sorun sahaları gözle görülür bir şekilde ortada bile olsa bu değişiklik ve yenilikler için yapılması gerekenlere karar verecek çalışanlar değildir. Çalışanların bu değişiklikleri yapma yetkisi yoktur. Kararların verilebilmesi ve çalışmaların başlatılıp hayata geçirilebilmesi üst yönetimin iradesi, gücü ve katılımını gerektirir.

Süreçlerin bir öncelik sırasına göre değerlendirilmesi ve iyileştirilmesi TKL'nin özünü oluşturur. Süreçlerin başlangıçta doğru olarak değerlendirilmesi neticesinde süreç basamaklarında büyük oranda verimsizlik ve israf tespit edilebilir. Yapılacak iyileştirme faaliyetleri ile bu verimsizlikler giderilerek maliyetler düşürülebilir. Böylece kıt kaynaklar diğer süreçlere aktarılabilir.

“... bugün ve gelecekte..." "Bugün” kelimesi mevcut süreçlerin kalitesinin iyileştirilmesini ifade etmektedir. "Gelecekte" kelimesi ise gelişen şartlara ve beklenen görev değişikliklerine hazırlık yapılması gerekliliğine işaret eder. TKL bu ihtiyaçları iki aşamalı bir yaklaşımla karşılar. Birinci aşama görev etkinliğinden sorumlu olan mevcut süreçlerin sürekli iyileştirilmesini kapsar. İkinci aşama son kullanıcıların muhtemel ihtiyaçlarını karşılamak için süreçlerin yeniden yapılanması ya da yeni ürün veya hizmetlerin yaratılması faaliyetlerini içerir.

“... tüm çalışanların bilgilerinin..." Birçok sürece ait bilgiler mevcut yönetim raporları ya da bilgi sistemleri içerisinde yer almaz. Bu bilgiler daha ziyade işi bizzat icra eden çalışanlar, memurlar, yöneticiler, eğiticilerin zihinlerinde saklıdır. Sürecin içindeki insanlar, iyileştirme için gerekli bilgi, fikir ve eylemleri üretmek için bir takım olarak çalışmalıdırlar.

TKL ile diğer problem çözme yaklaşımları arasındaki temel farklılık, analiz ve iyileştirmeyi yapan kişilerin sürecin performansından sorumlu süreç sahipleri olmalarıdır. "Genişletilmiş süreç" konseptinin açıklamasında da belirtildiği gibi sürecin anlaşılması ve iyileştirilmesinde müşteri ve tedarikçilerden elde edilen bilgiler oldukça yarar sağlamaktadır.

"...kantitatif metotların etkin olarak kullanılmasıdır." "Kantitatif metotlar" terimi verilerin yapısal olarak özetlenmesinde kullanılan istatistiki ve diğer grafiksel araçları içerir. Bu metotlar iyi ve kötü performansla ilgili faktörlerin, tanımlanması, anlaşılması ve kontrolüne yardımcı olur (Houston ve Dockstader, 1997).

Leithwood ve Steinbach (1993), TKL'nin dönüşüme ve değişime açık bir liderlik olduğunu vurgulayarak ABD eğitim sisteminde eğitici eğitimi açısından incelemişlerdir. Landa (1995), TKL'nin Arjantin ordusunda uygulanabilirliğini incelediği çalışmasında özellikle lojistik birimlerinde verimliliğin artırılması ve takım ruhunun geliştirilmesinde sağlayabileceği katkıları ortaya koymuştur. Cohen (1992), 
ABD Georgia eyaletindeki donanma lojistik üssünde uygulanmaya başlanan TKL'yi 5’li Likert Ölçeği kullanarak incelemiştir. Çalışmasında TKL uygulamalarının alt kademe çalışanlara ulaşamadığı sonucuna varmıştır. Cox (1997), Operasyonel liderlik ile TKL arasındaki ilişkiyi incelemiştir. Maganares (1993), gemi tersanesinde TKL uygulaması için Deming'in 14 noktasını kullanmıştır. Nicholls (1991), TKL'yi yaşanan değişime karşı gösterilen direnç yönüyle incelemiş ve bu dirençlerin kırılması için önerilerde bulunmuştur. Tikici vd. (2000), bankacılık ve finans sektöründe görev yapan yöneticileri astlar açısından TKL özelliklerine göre değerlendirmişlerdir. Hourani ve Hurtado (2000), sağlık alanında TKL'nin etkinliğini incelemişlerdir.

\subsection{Toplam Kalite Liderliği'nin Özellikleri}

Toplam Kalite Liderliği'nin başlıca özelliklerini aşağıdaki şekilde sıralamak mümkündür (Tikici vd., 2005) :

- Çalışanları hayalle yönlendirmek,

- Meslektaşlarını eğitmek, farklı görüşleri ve stratejileri birleştirerek sonuçları tasarlamak,

- Bütünüyle olaya yoğunlaşmak ve insanların görüşlerini olaydan sonra almak,

- Kritik bir nokta çıkabilir düşüncesiyle küçük şeyleri bile araştırmak,

- Rekabet ile eğlencenin bir arada olabileceğine inanmak,

- Organizasyonun etkisizliğini teşhis etmek ve tanımak için kaliteye sıçrama modeline başvurmak,

- İşleri, bilimsel olarak ayrıntılı şekilde incelemek,

- Sürekli takip edilen standartların yönlendirdiği, süreçler ve yöntemler oluşturmak,

- Liderlik yetenekleri ile yönetim yeteneklerini kalite yönetimi içerisinde güçlendirmek,

- Hem iç hem de dış müşterilerin gereksinimlerini bilmek,

- Proaktif olmak,

- Öncelikli şeyi ilk sıraya koymak,

- Otoriteye itaat etmek yerine, sistemi ve insanların becerilerini geliştirmeye çalışmak,

- Anlamayı, anlaşılır olmaya tercih etmek,

- Sinerji oluşturmak,

- Personeli güçlendirmek ve personele yetki vermek,

- İletişim sistemini hiyerarşiye göre değil ihtiyaçlara göre dizayn etmek,

- Açıkça ve geniş olarak anlaşılmış bir vizyonu uygulamak. 


\subsection{Toplam Kalite Liderliğinin Temel Konseptlerine Askeri Bakış Kalite Odaklılık}

Liderliğe kalite odaklı olarak yaklaşılacaksa; son kullanıcıdan devamlı geri besleme alınması ve organizasyonun birimleri içerisinde ve birimler arası düzenli iletişimin sağlanması hususları göz ardı edilmemelidir. Uygun ilişkilerin gelişimi TKL'nin uygulanmasına bağlıdır (Hourani and Hurtado, 2000)

Askeri birlik ve kurumlar için kalite, görev ihtiyaçlarının karşılanması olarak açıklanabilir (Houston ve Dockstader, 1997). Bu görev ihtiyaçları ürünleri içerebildiği gibi daha çok hizmet faaliyetleri ile ilgilidir. İkmal, sıhhi destek, istihkâm desteği, tam isabet vuruş yeteneği vb.

\section{Müşteri/Son Kullanıcı}

TKL; önceliği, kâr/zarar hesabına değil müşteriye veren bir yönetim felsefesidir. TKL'nin özel odağı müşterilerdir (Jaehn, 2000). "Müşteri” kavramı ürün veya hizmeti alan ve/veya kullanan kişileri ifade eder. Ticari hayatta kalite bu kişiler tarafından belirlenir. TKL yaklaşımı altında, kalite iyileştirme çabalarının amacı, muharip birlikler tarafından tanımlanan görev ihtiyaçlarının en iyi şekilde karşılanmasıdır (Houston ve Dockstader, 1997). Bu bakımdan muharip birlikler ve bu birliklerin personeli muharebe destek ve muharebe hizmet destek birliklerinin sağladığı hizmetin "müşsteri" leri ya da daha başka bir ifade ile "son kullanıcıları" dır. Bu nedenle ikmal, bakım, muhabere, istihkâm, sıhhiye v.b. hizmetlerin kalitesine karar verecek kişiler, muharip birlik personeli olacaktır. Başka bir bakış açısıyla; TKL'nin askeri birlik ve kurumlarda uygulanması iki aşamada karşımıza çıkabilir. Birinci aşama süreç yönetimi, ikinci aşama ise stratejik yöntemdir. Her iki aşama da organizasyonun bir sistem olarak algılanmasına dayanmaktadır. Organizasyon bir sistem olarak algılandığında sistemin girdisi, süreçleri ve çıtılarından bahsetmek gerekir. Bu sistemde kaliteye ulaşmak için müşteri tatmini esastır. Müşteri ise TSK'da "Personel"dir. Ayrıca bir de, "Dış Müş̧eri" kavramı vardır ki bu da ülkemiz ölçeğinde "millet ve devlet"tir. Aslında dış müşteri kavramı TSK'nın görev alanındaki genişleme kapsamında genişletilebilir. NATO, Barış İçin Ortaklık (Bİ) ve Birleşmiş Milletler (BM) kararları kapsamında birçok görev, değişik coğrafyalar da TSK'nın da katılımıyla icra edilmektedir. Dolayısıyla diğer dünya ülkelerinin silahlı kuvvetleri ve halkı da TSK'nın dış müşterileri olarak değerlendirilebilir.

\section{Süreç İyileştirme}

Süreç iyileştirme, süreç faktörlerinin kaliteyi arttıracak şekilde sistematik olarak analiz edilmesi ve geliştirilmesidir. Görev etkinliği; iyileştirme, yeniden tasarım ya da inovasyonla artırılabilir. Süreçler, daha tahmin edilebilir ve daha az maliyetli olduklarında ayrıca görev ihtiyaçlarının karşılanmasına sundukları katkılarla daha fazla geliştirilirler. Bu kavramdan, problemler ortaya çıtıktan sonra düzeltilmesinden ziyade önleyici tedbirlerin alınması anlaşılmalıdır (Houston ve Dockstader, 1997). 


\section{Süreç Yönetimi}

Süreç yönetimi, belirli süreçlerin sürekli iyileştirilmesini sağlayacak liderlik faaliyetlerini içerir (Houston ve Dockstader, 1997).

Askeri birlikler görev başarısını artırmak için tüm süreçleri etkin bir şekilde yönetmelidir. Bu kapsamda karşımıza süreç yaklaşımı çıkmaktadır.

Süreç yaklaşımı şu konuları kapsar (http://www.ilkerguven.com/):

$>$ Süreçlerin tanımlanması,

> Süreçler arası ilişkilerin çözümlenmesi,

> Süreç sahiplerinin belirlenmesi ve

> Süreç performansını ölçmek için kriter ve standartların belirlenmesi.

Bütün faaliyetler sistematik olarak süreçlerle yönetilmektedir. Süreçler anlaşılmış ve sahipleri belirlenmiş olmalıdır. Önlemeye yönelik iyileştirme faaliyetleri ile ölçüm ve istatistik tüm çalışanların günlük yaşamına entegre olmalıdır. Yönetim sisteminin temelini veriler, ölçüm ve bilgi sistemi oluşturmaktadır (http://www.profaj.com/).

\section{Genişletilmiş Süreç}

Bir organizasyon kaliteyi artırmak amacıyla, müşteri ve tedarikçileri ile birlikte genişletilmiş bir sistemin bir parçası olarak faaliyet gösterebilir ve göstermelidir. Müşteriler organizasyonun kalite anlaminda ürün ve hizmet karakteristiklerini iyileştirme çabalarına büyük ölçüde katkıda bulunacak bilgileri sağlayabilirler. Tedarikçiler ise organizasyonun görev ifa yeteneklerine etki edecek ürün ve hizmeti sağlamaktadırlar. Mevcut ihtiyaçları belirlemek için tedarikçilerle çalışma yapılması ya da süreç iyileştirme faaliyetlerinin tedarikçilerle birlikte yürütülmesi, hatalı üretimlerden kaynaklanan problemleri ya da yetersiz hizmetleri azaltacaktır (Houston ve Dockstader, 1997).

\subsection{Toplam Kalite Liderliğinin Dört Ön Şartına Askeri Bakış}

Uygulanan yönetim anlayış ve uygulamalarının TKL'ye dönüşüm süreci, TSK'da görevli tüm personelin faaliyetlerini etkileyeceğinden dolayı, TKL doğru olarak öğrenilmeli, planlanmalı ve sistematik bir şekilde uygulanmalıdır. Yanlış anlaşılmalara mahâl vermemek ve zihinsel bulanıklıkların önüne geçmek amacıyla aşağıda verilen ve TKL'nin ön şartları olarak nitelendirilen dört madde, liderlerin yapacakları çalışmalar sırasında kalite odağını kaybetmemelerine yardımcı olacaktır (Sniffin, 1994).

\section{(1) Her Alanda Öncelik Kalite Olmalıdır}

Pek çok organizasyonda liderler, kaynak ve öncelikleri ürün ve hizmetlerin, miktar ve maliyetleri üzerinde yoğunlaştırmaktadır (ör: günde kaç aracın tamiri yapılıyor vb.). Bu tür organizasyonlarda kalite yönetilmekten ziyade kontrol edilmektedir. TKL organizasyonunda ise, maliyetleri düşürmek, üretkenliği arttırmak 
ve kalitenin sürekliliğini sağlamak için tasarlanmış, ilgili tüm birimleri kapsayan bir yaklaşım söz konusudur. Bu nedenle uygulanan geleneksel yapıdan, TKL organizasyonuna geçiş süreci, basit düzenlemeler yapılması ve organizasyonel önceliklerin değiştirilmesinden daha fazlasını gerektirmektedir. Dönüşüm, liderin komutası altındaki tüm süreçlerin iyileştirilmesinin yanı sıra, kalite odağını oluşturmak ve sürdürmek için gerekli kültürel değişimlerin anlaşılmasını ve uygulamaya konmasını gerekli kılar.

\section{(2) Kalite Yolculuğuna Liderler Önderlik Etmelidir}

TKL dönüşüm ve değişim sürecinin her kademede ki liderler tarafından optimal bir şekilde yönetilmesi büyük önem taşımaktadır. Çünkü;

- Öncelikle TKL bir program değil, organizasyondaki liderler tarafından tüm organizasyon bünyesinde uygulanan bir yönetim ve liderlik sistemidir.

- İkinci olarak, TKL dönüşümü, tüm göreve yönelik süreç, ürün ve hizmetlerin geliştirilmesini gerektirdiğinden uzun zaman alacaktır.

- Son olarak TKL dönüşüm sürecini yönetme sorumluluğu devredilemez.

Gerekli dönüşüm ve değişiklikler sadece liderler tarafından gerçekleştirilebilecek niteliktedir.

\section{(3) TKL'nin Amacı Görev Performansını Artırmak Olmalıdır}

TKL'nin ana amacı görev ihtiyacının karşılanması ve müşteri/son kullanıcı memnuniyetinin sağlanması prensibine dayanmaktadır. TKL eğer doğru uygulanırsa, diğer yararlı getirilerinin yanında, personelin moralinin ve organizasyonel etkinliğin de artmasını sağlayacaktır.

TKL'nin çıkış noktası, her faaliyetin bir müşterisi olduğu düşüncesine dayanmaktadır. TSK'da alt düzey personel icra edilen süreçlerin müşterileri, yani son kullanıcılarıdır. Ayrıca muharip birlikler, muharebe destek ve muharebe hizmet destek birliklerinin müşterisi durumundadırlar.

Muharebe şartlarında başarılı olabilmek için öncelikle müşteri/son kullanıcıların istek ve ihtiyaçlarının barıştan itibaren belirlenmesi ve iyileştirmelerin bu ihtiyaçları karşılayacak şekilde sistematik olarak gerçekleştirilmesi gerekmektedir.

TKL müşteri ve görev ihtiyaçlarını karşılamak ve aşmak için, geçmişte kullanılan metotlardan tamamen farklı bir metodoloji sağlamaktadır. Yaklaşımın uygulanma aşamasında ise, birçok kişi, özellikle kıt'a da görev yapan liderler için, kalite gereksinimlerini tanımlamak oldukça güç olmaktadır. Ancak görev performansının farklı yönleri için ayrıntılı tanım ve ölçütlerin geliştirilmesi, dönüşüm sürecinin ilk önemli basamağını oluşturmaktadır. Yüzeysel ve sürekli değişen tanımlarla, kalitenin gerçekleştirilmesi mümkün değildir. Bu nedenle öncelikle "kaza", "disiplin", "vukuat" vb. terimlerin herkes için aynı şeyi ifade edecek şekilde operasyonel olarak tanımlanması gerekmektedir. 
Dönüşüm sürecinin ikinci basamağı ise, görev performansına katkı sağlayacak kritik süreçlerin tespit edilmesi ve belirlenen bu süreçlerin sürekli iyileştirilmesidir.

\section{(4) Dönüşüm Süreci Sistem Yaklaşımı Bakış Açısıyla Gerçekleştirilmelidir}

Organizasyonel performansın iyileştirilmesi liderlerin sorumluluğudur. Deming sistem optimizasyonunu "belirli bir amacın gerçekleştirilmesine yönelik tüm unsurların çabalarının yönetilmesi süreci" şeklinde tanımlamaktadır. Burada kastedilen optimizasyon; sistemin unsurlarının, aralarındaki ilişkilerin ve sistemi etkileyen çevresel faktörlerin anlaşılması ve yönlendirilmesini içeren sonsuz bir faaliyettir. Liderler optimizasyonun sürekliliğini sağlayabilmek için iç ve diş değişikliklerin farkında olmalı ve gerekli düzenlemeleri yapmalıdırlar. Ayrıca sistemin optimum olarak çalışması için farklı unsurlar arasındaki dengeyi kurmalı ve korumalıdırlar.

İyileştirme her seviyede yapılabilecek bir faaliyet olmakla birlikte, önemli ve kalıcı kazançlar elde etmeyi sağlayacak temel faktör, değişiklikler için mutlaka yönetimin katılımının sağlanmasıdır. Göreve yönelik tüm süreçlerin bir öncelik sırası dâhilinde değerlendirilmesi ve iyileştirilmesi TKL'nin özünü oluşturur.

\section{TÜRK SİLAHLI KUVVETLERİ VE TOPLAM KALİTE LIDERLIĞĠ}

Soğuk savaşın bitmesi ve Doğu Bloku'nun yıkılması dünyada küreselleşmeyi hızlandırmış ve dünya politikasının belirlenmesinde etkili olan ülkelerin değişen koşullara uygun yeni stratejiler geliştirmelerine yol açmıştır. Globalleşmenin en belirgin sonucu, rekabetin sertleşmesi olarak karşımıza çıkmıştır. Ekonomik anlamda sınırların ortadan kalkmasıyla ülkeler arasında sinerjik etki yaratılmış ve karşımıza yeni ve güçlü oluşumlar çıkmıştır. TSK'nın dış belirsizlikleri bertaraf etmesi ve rekabetçi bir dünyada etkinliğini sürdürebilmesi, TKY uygulamasıyla başlatılacak yeni bir uygulamayı zorunlu hale getirmiştir. Bu yüzden TKY bir moda değil, ihtiyaç olarak ortaya çıkmaktadır.

21'inci yüzyıla girerken organizasyonlarda gerçek verimliğe ulaşmanın tek yolunun insandan daha etkin olarak faydalanabilme gerçeği olduğu ortaya çıkmıştır. TSK'nın gerçek sermayesi de insandır. Gelecekte güçlü ordu imajını muhafaza edebilmesi ve dünyadaki değişimlere ayak uydurabilmesinin sırrı insanın içindeki dinamikleri uyandırmaya bağlı olacaktır. Teknoloji ne kadar gelişirse gelişsin geleceğin olası muharebelerini kazanma noktasında son sözü yine insan söyleyecektir.

TKY sadece üründe değil; hizmette, iletişimde, fikir alanında ve yönetimin her alanında, hatta çevrede dahi kaliteye ulaşılmasını hedeflediğinden uygulanması zor bir yönetim felsefesidir. Günümüzde artık TKY felsefesinin bu düşünce sistemiyle sadece ticari anlamda değil, kamu alanlarında da uygulanmasını zorunlu hale getirmiştir.

Artık dünyada gelişen teknolojiler ve insan kaynakları dikkate alındığında ülkelerin silahlı kuvvetlerinin değişime ayak uyduramadıkları takdirde etkinliklerini yitirme ve sonunda yok olma tehlikesiyle karşı karşıya kalmaları söz konusu olacaktır. 
TSK'da TKY uygulamalarına 1997 yılında başlanmıştır (Gnkur. Bşk.lığının 21 Kasım 1997 tarih ve “TKY Uygulama Direktifi-1" emri ile). Bu tarihten itibaren TKY yaklaşımı meyvelerini vermiş ve kurumsal olarak verimliliğin sürdürülebilir kılınmasında kullanılan en önemli argümanlardan biri olmuştur.

TKY anlayış ve felsefesinde; liderin önemi, görev ve sorumlulukları ile eğitimi gibi kavramlar genel olarak uygulanma şansı bulurken, temelleri Deming'in öncülügüunde atılan TKL uygulamaları içinse kurumsal çerçevede özel bir adaptasyon çalışması yürütülmemiştir. Bunun yanında Özellikle Deming'in görüşlerinin ABD Deniz Kuvvetleri için adapte edilmesi önümüze önemi bir örnek uygulama sunmaktadir.

Yukarıda ana hatları çizilen TKL anlayışının uygulanması için Deming'in ünlü 14 noktasını yeniden düzenlenmiş ve liderlik yaklaşımında bir kılavuz olarak sunulmuştur (Maganares, 1993). Deming'in bu 14 noktalı yönetim felsefesinin TSK açısından sağlayabileceği katkılar şu şekilde değerlendirilebilir.

\section{(1) Hizmet ve ürünlerin geliştirilmesi için amaç sürekliliği yaratmak}

Kimse bir hedefe karar vermeden hedef sürekliliğine sahip olamaz. Bu yüzden, hedef sürekliliği ilkesini uygulamak isteyen herkes işe, hedefini ve bu hedefe ulaşmak için gerekli amaçlarını belirterek başlamalıdır. Bu kapsamda uygun vizyon, misyon ve değerlerin belirlenmesi bir başlangıç oluşturmaktadır. TKY'yi uygulayan bir organizasyonun lideri belli bir misyon yaratarak bu misyonun herkes tarafından doğru olarak algılanmasını sağlamalıdır. Bunun yanında lider, organizasyonun misyonunun gerçekleşmesi için ihtiyaç duyulan argümanları da sağlamayı taahhüt etmelidir.

Silahlı Kuvvetlerde lider denildiği zaman sadece organizasyonun en üst kademesi algılanmamalıdır. Başkalarına bir şeyi yaptırma durumunda olan herkes liderlik mekanizmasına dâhildir. Bu kapsamda bir tim komutanının liderliğinden söz edilebileceği gibi, bir mutfak çavuşunun da liderliğinden söz edilebilir. Liderler astlarıyla aralarında, onların barışta ve savaşta doğru şeyler yapmalarını sağlayacak bir takım bağlar oluşturmalıdır. Liderlik tarzlarının seçimi ve icrası; kişiden kişiye, ortamdan ortama, zamandan zamana ve durumdan duruma farklılık göstermekte ve liderlik tarzlarının seçiminde durumsallık yaklaşımı önem kazanmaktadır.

\section{(2) Yeni bir toplam kalite ve sürekli gelişim felsefesi benimsemek}

Organizasyonlar ellerindeki kısıtlı kadro ve kaynaklarla müşterileri için zaten ellerinden gelenin en iyisini yapmakta olduklarına inanma tuzağına düşmekten kaçınmalıdırlar. Bu inanç, süreçlerin gereksiz tekrarlar, fazlalıklar, bürokrasi ve gecikmelerle tıkanmış olduğu gerçeğini dikkate almaz ve müşterilerin, organizasyonları oldukları gibi kabul etmelerini sağlar. Gereksiz engeller kaldırıldığında müşterilerin ihtiyaçlarını karşılama yeteneği dikkat çekici bir biçimde artacaktır. Bu kapsamda lider, değişimin liderliğini üstlenmelidir.

Silahlı Kuvvetler'de ise sunulan eğitim; verilen hizmet veya icra edilen harekâtın nev'ine göre her kademedeki lider, TKL çerçevesinde bir yönetim anlayışı 
sergilemeli, etki alanında sürekli gelişim faaliyetlerine öncülük ederken; ilgi alanına da pratikleriyle örnek olmalıdır.

(3) Kaliteye Ulaşmak İçin Kontrolü Temel Almaktan Vazgeçin-Bütün halinde denetlemeye son verin

Kontrol çoğu zaman gerekli ve önemli bir faaliyettir. Örneğin, atış eğitimde, atış hattında iken geride kalanların ellerinde mühimmat olup olmadığının kontrolü hayati kazaları önler. Ya da motorlu intikale çıkmadan yakıt depolarını kontrol etmek aksaklıkların önceden engellenmesini sağlar. Bu noktada belirtilmek istenen konu, gerekli kontrolleri ortadan kaldırmak değil, sadece kontrol yoluyla kalitenin sağlanamayacağı hususunun vurgulanmasıdır. İyiyi kötüden ayırmak ve kötü üzerinde tekrar çalışmak en sonunda hatasız bir şey üretmeyi sağlar ama bu; verimsiz, masraflı, çok yavaş işleyen ve ne getireceği bilinmeyen bir yöntemdir.

Kaliteye ulaşmanın daha iyi bir yolu; süreçleri, üretilen ürün ve sağlanan hizmet üzerinde tekrar çalışmayı gerektirmeyecek biçimde iyileştirme sağlamaktır. Burada toplam kalite liderinin rolü; en az maliyetle, kontrolü ortadan kaldırmadan; aksine kontrollerin alışkanlık haline getirilmesini sağlamaya öncülük etmektir.

(4) Sadece Fiyat/ Maliyet Temelli İş Verme Uygulamasını Kaldırın. Uzun Dönemli Güven ve Sadakat Duygularıyla Hareket Edin

Toplam Kalite Lideri; bulunduğu birimin (Tb./Bl./Tk./Ks. vb.) başında astları arasındaki yatay ilişkiyi yakından gözlemleyerek aralarındaki koordinasyonu sağlamalıdır. Her zaman aynı birime görev vermek yerine birbiri ile bağımlı görevlendirmeler yapmalı ve alt kademe kalite liderlerine öncülük etmelidir. Bunları sağlarken de güven ve sadakati ön planda tutmalıdır.

Süreç çıktılarının kalitesi, çoğunlukla tedarikçilerin (destek sağlayan diğer birimler) desteğine bağlıdır. Tedarikçi bölümler sistemin uyumlu çalışması kaygısıyla yönetilmediğinde, müşterilerinin ihtiyaçlarını göz ardı edebilirler. Bu müşteriler de, kendi müşterilerinin ihtiyaçlarını göz ardı edebilirler. Tüm birimlerde bu göz ardı etme zincirine son verecek kişi yine toplam kalite lideridir.

\section{(5) Sürekli Olarak ve Sonsuza Kadar İyileştirin}

Bu madde, 3. madde ile beraber ele alınmalıdır. Deming'in 14 maddesi birleşik bir yönetim teorisi olarak bir arada etkili olduğundan; 3. ve 5. maddeler bütünleşik olarak değerlendirilerek sürekli süreç iyileştirme ihtiyacının önemini vurgulanmış olur. 3. maddede vurgulandığ 1 gibi kaliteye ulaşmakta kontrolü temel almamalı; onun yerine üretim ve hizmet sistemini (süreçlerini) sürekli olarak ve sonsuza kadar iyileştirerek kaliteye ulaşmak amacıyla 5. madde uygulanmalıdır.

İşleri yapmanın tek bir en iyi yolu olduğu inancını değiştirme konusunda öncülüğü toplam kalite liderleri üstlenmelidir. Birimler amaçlarını sadece bozulmuş süreçleri onarmak olarak görmemelidirler. Zaten süreçlerin pek çoğu önceden de doğru işlemediğine göre onları eski hallerine getirmekte çok bir fayda sağlamayacaktır. Süreçleri iyileştirmeden önce, süreçlerin nasıl işlediğine dair bilgi edinilmeli ve yeterli 
bilgi edinildiğinde süreçlerin nasıl iyileştirileceğinin ortaya konması gereklidir.

\section{(6) Mesleki Eğitimleri Kurumsallaştırın}

Organizasyonun tüm üyeleri yapacakları iş konusunda eğitilmelidirler. TSK'da özellikle liderler: deneyimli birinin yönetiminde kalite öğretileri, takım toplantısı becerileri, iyileştirme stratejileri, uzlaşım ve istatistik araçları konularında eğitim alabilmeli; yine deneyimli birinin gözetiminde, gerçek bir takım toplantısında bu bilgileri uygulama fırsatı bulabilmelidirler. Alt kademe diğer personel de verilen görevin nev'ine uygun olarak oryantasyon, başlangıç, fırsat, tekamül ve görev başı eğitimlerine tabi tutulmalıdır. Toplam Kalite Liderlerinin astlarını eğitme ve eğitimin sürekliliğini sağlama görevi bulunmaktadır. Bu bağlamda eğitimin sürekliliği ve kurum politikası haline gelmesi bir etkililik ve verimlilik aracı olarak görülmelidir.

\section{(7) Liderliği Kurumsallaştırın}

Toplam Kalite Liderlerinin, kalitenin sağlanması ve sürdürülebilir kılınması için iki amacı bulunmaktadır. İlk amaç, kendilerine görev verilen süreçlerde iyileştirebilmeleri gerçekleştirmektir. Süreçleri iyileştirebilmek için, bu süreçlerin organizasyonun amaçlarına nasıl katkıda bulunduğunu anlamaları gerekir. Ayrıca, iyileştirme stratejilerinin nasıl kullanılacağını da anlamış olmaları gerekir.

Toplam Kalite Liderinin ikinci amacı, organizasyon kültürünü değiştirebilecek bir güç haline gelmektir. Liderler birimlerinin başına geçtiklerinde TKY öğretilerini kavrama konusunda bir hayli mesafe almış olmalıdırlar. Sistemlerin ya da süreçlerin önemini ve bir amacın gerçekleştirilebilmesi için bir süreçteki bütün tedarikçi ve müşteriler arasında işbirliği olması gerektiğini takdir edebilmelidirler. Aynı anlayışı birimdeki diğer üyelere de aşılayabilmelidirler. Liderler bunu gerçekleştirebilmek için kendi liderlik becerilerini nasıl iyileştirebileceklerini ve birimlerini nasıl daha etkili kılabileceklerini öğrenmeyi istemelidirler.

TSK'da ki her kademe lider aynı zamanda toplam kalite lideri de olduğuna inanıldığında zaten liderliğin de kurumsallaşacağı aşikardır.

\section{(8) Korkuyu Söküp Atın}

Toplam Kalite Liderleri bütün beyinlerin hiyerarşinin tepesinde toplanmadığını bilirler. Süreçleri iyileştirecek en uygun kişilerin o süreçlerde çalışanlar olduğunu kabul ederek onların fikirlerinin kazanıma dönüşmesini sağlarlar. Korku ve baskı ortamında bireylerin fikirlerini ortaya çıkarmalarını beklemek uygun bir yaklaşım olmayacaktır. Organizasyonun çatısı altında bulunan herkesin işini ve kurumunu sahiplenmesi, onları ileriye taşıma düşüncesini taşıması ve bu doğrultuda motive edilmesi son derece önemlidir. Bütün bu motivasyonun sağlanabilmesi de korkunun hakimiyetine son vermekle kazanılabilir.

TSK askerlik mesleğinin getirdiği katı hiyerarşik yapısı nedeniyle korku kültürünün çok çabuk gelişmesine uygun bir yapı sergilemektedir. Liderlerin astlarıyla olan güç mesafesini azaltması, biz ve ekip olgularını yerleştirmesi ile korku ortamı yerini işbirliği, saygı ve dayanışmanın hâkim olduğu bir ortama bırakacaktır. Bu da 
söylenildiği kadar kolay olmayıp liderler de maharet gerektirmektedir. Korku kültürünün askerliğin temeli ve disiplinine aykırılık teşkil etmeden ortadan kalkmasıyla tam katılım sağlanmasının önü açılacaktır.

\section{(9) Bölümler Arasındaki Engelleri Yıkın}

Toplam Kalite Lideri bölümler/birimler arasındaki engelleri yıkmak için gereken ortamı hazırlamak amacıyla, organizasyon üyelerine kuruluşu bir sistem

olarak değerlendirmeyi öğretmelidirler. Üyeler, sistemin bütün unsur ya da bölümlerinin, kuruluşun amacını gerçekleştirmek için işbirliği içinde çalışmaları gerektiğini anlamalıdırlar.

TSK içerisinde farklı alt birimlerin birbirlerini zaman zaman desteklemek; takviye etmek hatta emrine vermek gibi görevleri vardır. Burada toplam kalite liderinin asıl farkındalığı aynı amaca hizmet eden farklı birimler olduğunu astlarına öğretmek ve gerekli işbirliği ve koordinasyonun sağlanması sayesinde ana birimin görevini başarabileceği gerçeğini anlatabilmektir.

\section{(10) Sloganları ve Nasihatleri Ortadan Kaldırın}

Slogan ve nasihatlerle organizasyon üyelerini daha fazla çaba harcamaya zorlamak, onlar zaten ellerinden gelenin en iyisini yapmaya çalışırlarken cesaret kırıcı bir etki, hatta bir hakaret etkisi yaratabilir. Slogan ve nasihatler, üyelerin nasihat almadıkları takdirde iyi iş çıkarmayacakları gibi olumsuz bir algı oluşturabilir.

TSK'da özelinde ise toplam kalite liderlerinin dengeli bir yaklaşım benimsemeleri gerekmektedir. İnsan kaynağının çoğunlukla erbaş ve erler olduğu gerçeğinden hareketle yeteri kadar nasihat (emniyet brifingleri ve emirler) ve yeteri kadar birlik beraberliği sağlayıcı slogan geliştirmek rasyonel bir yaklaşım olacaktır.

(11) Çalışma Standartlarını ve Hedeflerle Yönetimi Ortadan KaldırınLiderlikle yer değiştirin

Geleneksel yönetim ve liderlik anlayışının bir mirası da çalışma zamanının ve ürün/hizmet standartlarının sıkı hedeflerle bağlı olmasıdır. Hedeflere ulaşmanın tek yolu ve ulaşılacak seviyenin tek göstergesi olarak standartlar ortaya konulmuş ve standartlara ulaşmak yeterli görülmüştür. Aynı şekilde hedeflere ulaşmak için süreçler yeterince dikkate alınmaksızın zaman tahditleri konulmuş ve başarının tek göstergesi olarak gösterilmiştir.

Örneğin bir iyileştirme sürecinin belli kısa bir zaman aralığında tamamlanması düşüncesine sahip olan bir kimse, yalnızca aksayan bir süreci eski haline getirmek düşünce ve hedefine sahiptir. Sürekli iyileştirmeyi düşünmüyor demektir. Oysa 5. maddede açıklandığı gibi iyileştirme sürekli olarak yapılan dinamik bir olgudur.

TSK'da da görevin gerektirdiği faaliyetlerin zamanın da yetiştirilmesi ve standartlara ulaşması son derece önemlidir. Planlama ve koordinasyon eksikliğinden kaynaklanan gecikmeler yoğun mesai ve ağır çalışma şartları gerektirir. Bu durumda istenmeyen olumsuzlukları (kalite azalması, iş kazaları, stres vb.) beraberinde getirir. $\mathrm{Bu}$ noktada kalite liderleri süreçlerinde insan kaynakları ve zaman yönetimi 
fonksiyonlarını etkinlik ve verimlilik aracı olarak kullanmalı ve beklenmeyen olumsuzlukları en aza indirmelidir.

Yine iyileşmenin ve kalitenin göstergesi olarak standartlar koymak ve bu standartlara ulaşmayı da yeterli görmek kalite yaklaşımının önünde büyük bir engeldir. Kalite anlayışı devamlı gelişmeyi öngörür. Minimum gösterge olarak konulan standartların üst sınırı hiçbir zaman sınırlandırılmalı, konulan minimum standartlar da devamlı geliştirilmelidir. TSK'nın vizyonu ve bu doğrultuda oluşturulan amaç ve değerleri geleceğin muharebe ortamında beklenen değişikliklere paralel olarak süratli bir değişim göstermektedir. Bu değişime paralel olarak sistem, süreç ve personelinde yeteneklerini aynı doğrultuda geliştirmesi ve değişime ayak uydurabilmesi kalitenin temel dinamiklerinden olan sürekli değişim ve gelişim anlayışıyla sağlanabilir. Kalite anlayışının gelişimini engelleyen sıkı standart yaklaşımı ortadan kaldırılarak TSK'nın yetenek tabanlı harekat kabiliyeti artırılabilir.

(12) İnsanların Yaptıkları İşten Gurur Duymalarını Önleyen Engelleri Ortadan Kaldırın

Organizasyonda bir bütünün parçası olarak yapılan her faaliyette personelin tamamının katkısı olduğu hissi toplam kalite liderlerinin sık sık hatırlatacağı konulardan birisidir.

TSK'nin hiyerarşik yapılanmasında alttan üste doğru çıkıldıkça daha önemli olunduğu yönündeki hissin neden olabileceği önemsizlik duygusunun başarının önünde bir engel teşkil etmesi önlenmelidir. Bu maksatla, hiyerarşik yapının sadece yönetime ilişkin teksesliliğinin sağlanması amacıyla uygulandığı; karar almada, başarının sahiplenilmesi ve ödüllendirilmesinde, başarısızlığın da ortak olarak göğüslenilmesinde tüm kademelerin eşit katılımının olduğu hissiyatının gruba benimsetilmesi grup aidiyetini geliştirmede katkı sağlayacaktır.

Aidiyet duygusunun geliştiği bir yapılanmada da yapılan işten ve sağlanılan katma değerden gurur duyma doğal bir sonuç olacaktır.

\section{(13) Canlı Bir Eğitim Programı Yürütün}

Çevremizde, muhakeme yeteneği gelişmiş, görev heyecanı bulunan ve hevesli oldukları halde başarılı olarak isimlerini duyamadığımız birçok insan bulunmaktadır. $\mathrm{Bu}$ tür kişiler, kibirli ve sürekli eleştirel bir yapıda olup, bilgi seviyeleri yüksek, herhangi bir işte başarı yerine, sürekli mazeret üreten, yeni bir faaliyete başlama enerji seviyeleri düşük olan, başladığında da yapılacak işler ajandalarına kaydedip bir daha bakmayan kişilerdir.

Bahsedilen yapıda bulunan kişiler, kendilerine verilen görevleri yerine getirir, ancak kendilerinden bir katkıda bulunmazlar. Bu tür davranışın birçok nedeni olabilir, fakat asıl neden bu insanların kariyerlerinde ilerleme hedeflerine ulaşmada başarısızlık olabilir. Bazıları kendilerini geliştirme çabasını bırakmış, yıllardır bu maksatla kitap okumamış olabilirler. Televizyon seyretmek ve gazetelerin spor sayfalarını okumak dışında yeni bir fikirle karşılaşmamış olabilirler. Bu tür insanlar zihinlerini yeniden harekete geçirecek bir motivasyona ihtiyaç duyarlar. 
Çalışanları yeterince motive edemedikçe ve yaratıcılıklarını harekete geçirmedikçe, herhangi bir grubun gerçekten başarılı olabilmesi mümkün değildir. TSK' da da kalite yönetimi anlayış ve uygulamaları sayesinde, bu konularda kafa yoran liderler yetiştirilerek, mevcut liderlerin motivasyonlarının artırılması ve dinamizmin canlandırılabilmesi sağlanabilir.

\section{(14) Dönüşüm Herkesin İşidir-Değişim Bir Süreçtir}

Dönüşüm ve değişim sadece, üst yönetimin çalışanlara kalite ve verimlilik öğretileri hakkında eğitim vermesi ve bunları uygulamaları yolunda tavsiyelerde bulunmasıyla gerçekleştirilemez. Üst yönetimin, harekete geçmesi ve yönetimin kararlılığını göstererek çalışanlara görev heyecanı aşılaması gerekmektedir. Özellikle alt kademe çalışanların motivasyon ve yeteneklerinin seferber edilmesi için özel bir çaba gereklidir.

Bu doğrultuda TSK'da görev yapan liderler ve üst düzey yöneticiler değişim ve dönüşümü önce kendileri benimseyerek astlarını bu doğrultuda yönlendirmelidirler. $\mathrm{Bu}$ hareket bir baskı unsuru oluşturularak sağlanan yönlendirme olmamalı, tüm personel değişimin ve dönüşümün gerekliliğini anlayarak; uygulamaya geçirilen yenilikleri kendi fikirleri gibi benimsemelidirler. Bu noktada yine toplam kalite liderliği TSK'ya katkısını sunacaktır.

Yukarıda açıklanan ve adapte edilen 14 noktalı yönetim felsefesiyle şekillenen TKL anlayış ve uygulamalarının literatürde ABD Deniz Kuvvetleri hastane (Hiland, 1991), tersane (Maganeres, 1993) ve operasyonel deniz gücüne (Theodossiou, 1993), TSK'da eğitim birliğine (Şen, 2005), vizyon oluşturma sürecinde yönetim anlayışına (Gencer, 2008) ve akademi eğitimine (Taştekin, 2000) uygulayan yazarlar özellikle; yönetim, tam katılım, ekip ruhu, işbirliği ve koordinasyon, maliyetlerin azaltımı, ürün ve hizmet kalitesinin korunarak yükseltilmesi, kazaların önlenmesi gibi katkılar sağlayacağını ortaya koymuştur. Benzer şekilde bizde bu katkıların TSK özelinde elde edilebileceği kanaatindeyiz.

Daha önce de bir kısım ülkelerde gerek sivil sektör gerekse kamu kurumlarında ve kamu özelinde ülkelerin silahlı kuvvetlerinde araştırılma ve uygulanma fırsatı bulan TKL'nin sağladığı katkılar son derece önemlidir.

$\mathrm{Bu}$ açıdan TSK'da da, TKL öğreti ve uygulamalarından istifade edilerek geleceğin liderlerinin yetiştirilmesi ve kurumun bugün olduğu gibi gelecekte de görevini en iyi şekilde yapması sağlanabilecektir.

\section{SONUÇ}

Geçtiğimiz yüzyılın son yarısından itibaren yönetim alanında önemli değişimler yaşanmıştır. Bu değişimlerin en önemlilerinden biri TKY anlayışıdır.

TKY için yapılan birçok farklı tanımın ortak noktaları ele alındığında, müşteri memnuniyetini esas amaç olarak görmek, sürekli gelişim, kalitenin bütün süreçlere yayılması ve tam katılım gibi prensipler ön plana çıkmaktadır. TKY, bir yönetim felsefesi olarak getirdiği avantajları sayesinde Türkiye' de ve dünyada giderek daha çok 
kullanılır hale gelmiştir. TKY'nin dayandığı temel ilkelere bakıldığında liderliğin ne kadar önemi olduğu açıkça görülmektedir.

Bu bağlamda TKL kısaca; Organizasyonda kalitenin iyileştirilmesi için sürekli çaba gösteren ve Toplam kalite felsefesini benimsemiş bir liderlik anlayış ve uygulamasıdır. Kalite, taviz verilmeyecek bir ilke sürekli daha iyiye giden sonsuz bir yolculuktur. Japonların "kaizen” (sürekli geliştirme, iyileştirme) tekniğini kullanan; organizasyonda en üst seviyeden en alt seviyeye kadar herkesin yaptığı işin önemine inanması, en iyisini özenle yapmaya çalışması ve sıfır hata hedefini yakalaması için uğraşan bir liderlik anlayışıdır (Karataş, 2006).

Başarılı bir şekilde uygulandığı zaman TKL; maliyetleri düşürmek, verimliliği artırmak, atıl kapasiteleri kullanmak, çalışanların motivasyonunu artırmak ve müşteri memnuniyetini sağlamak gibi hayati faydalar sağlamaktadır.

Özellikle ABD Deniz Kuvvetleri bünyesinde TKL'nin araştırılması, uygulanması ve pratikler geliştirilmesi amacıyla Toplam Kalite Liderliği Ofisi kurulmuştur.

Spesifik olarak yapılan araştırmalar incelendiğinde Silahlı kuvvetler özelinde TKL'den en fazla üretim yapan ve hizmet sağlayan birimlerin faydalanabileceği görülmektedir. Bunların içerisinde en iyi uygulama ve adaptasyonların bakım-onarım, sağlık ve eğitim birlik/kurumlarında hayata geçirilmesi TKL'nin kalite, maliyet ve müşteri odaklı anlayışının bir gereği olarak düşünülebilir.

TKY'nin uygulanmaya başlandığı 1997 yılından itibaren TSK'da yaşanan gelişmeler, TKL'den de yaygın olarak istifade edilmesiyle daha ileri bir noktaya taşınabilir.

Literatürde TKL'nin askeri uygulamalarına bakıldığında; kaza ve olaylarda TKL uygulaması sonrasında \% 48 azalma sağlandığı (Hiland, 1991), fiili silah atışlarında başarı yüzdesinin \% 93' e çıtı̆̆ (Theodossiou, 1993), personelin katkıları ile gerçekleşen sonuç alınan iyileştirme faaliyetleri sayısı \% 89 oranında artış elde edildiği (Taştekin, 2000), personelin gemi bazında gerçekleştirdiği bakım onarım faaliyetlerinde \% 79'luk bir artış sağlandığı, onarım kademelerinde kişi başına arıza onarımı, miktar ve süre açısından 5 kat azaldığı, gemi bazında faal olma sürelerinin 7 kat arttığı (Maganeres, 1993), disiplin olaylarında 8 kat azalma olduğu tespit edilmiş (Şen, 2005) ve personel memnuniyeti \% 79 olarak ölçülmüştür (Gencer, 2008). TKL uygulamalarının TSK'nın diğer birimlerinde aktif olarak uygulanması neticesinde benzer başarıların elde edilebileceği değerlendirilmektedir.

TSK mevcut sıkı merkeziyetçi ve hiyerarşik yapısı ile genelde klasik yönetim tarzını sergilemektedir. Klasik yönetim tarzı toplam kalite yönetimi ile taban tabana zıt bir yapı sergilemektedir. Başlangıçta, TSK bu yapısı kültürel değişimi esas alan toplam kalite yönetimi karşısında bir engel olarak algılanabilir. Ancak bütün bunlara rağmen; toplam kalite yönetiminin bir kez birliklerimiz tarafından benimsenmesi durumunda, TSK'nın gelenekçi ve yenilikçi yapısı bir araya gelince başarı kaçınılmaz olacaktır. Zira 
tecrübeler göstermiştir ki, gelenekçi toplumlarda kurum kültürü veya organizasyon kültürü yaratmak daha kolay olmaktadır.

\section{KAYNAKÇA}

Atatürk, M.K. (1989). Subay ve Komutan İle Konuşmalar. İstanbul: Harp Akademileri Basımevi.

Cohen, G. K. (1992). An Assessment Of The Implementation Of Total Quality Leadership At Marne Coprs Logistıcs Base,Albany, Georgia, (Yüksek Lisans Tezi), Naval Postgraduate School, ABD.

Cox, A. L. (1997). Total Quality Operational Leadership: The Role of Total Quality Leader in Joint Military Operations, Naval War College, ABD. 28 Aralık 2012'de http://www.dtic.mil/dtic/tr/fulltext/u2/a325243.pdf adresinden alınmıştır.

Doğan, S. (2007). Vizyona Dayalı Liderlik, Kare Yayınları, İkinci Baskı, İstanbul.

Gencer, R. (2008). Toplam Kalite Yönetimi (TKY) düşüncesiyle TSK'da verimlilik nasıl arttırlabilir, vizyonu belirlemede hangi kriterler değerlendirilir? (Yüksek Lisans Tezi), Harp Akademileri Komutanlığı, İstanbul.

Hiland, J. (1991). Development of a Total Quality Leadership Implementation Roadmap for Naval Hospital, Georgia, (Yüksek Lisans Tezi), Naval Postgraduate School, ABD.

Hourani L. L. ve Hurtado, S. L. (2000), Total Quality Leadership in the U.S. Navy :Effective for Health Promotion Activitie, Preventive Medicine, 30 (6), 478-484.

Houston A., ve Dockstader S.L. (1997). Total Quality Leadership: A Primer, TQLO Publication Number 97-02, Department of the Navy Total Quality Leadership Office, Virginia, USA. 28 Aralık 2012'de http://www.balancedscorecard.org/portals/0/pdf/primer.pdf adresinden alınmıştır.

Jaehn, A.H. (2000). Requirements for Total Quality Leadership, Intercom, 47(10), 38-46.

Karataş, F. (2006). Liderliğin Birinci Penceresi: Toplam Kalite Liderlĭ̆i, 29 Aralık 2012'de http://blog.milliyet.com.tr/liderligin-birinci-penceresi--toplam-kaliteliderligi/Blog/?BlogNo=7720 adresinden alınmıştır.

Karatay, Ş. (2006). İlköğretim Okulu Yöneticilerinin Öğretim Liderliği Davranışları, (Yüksek Lisans Tezi), Selçuk Üniversitesi Eğitim Bilimleri Enstitüsü, Konya.

Kayıkçı, K. (1999). Toplam Kalite Yönetiminde Liderlik, Kuram ve Uygulamada Eğitim Yönetimi Dergisi, 5 (20), 570-584.

Landa, G. A. (1995). Assessment of the Applicability of Total Quality Leadership into the Argentine Army, (Yüksek Lisans Tezi), Naval Postgraduate School, ABD.

Leithwood, K., ve Steinbach, R. (1993). Total Quality Leadership: Expert Thinking Plus Transformational Practice, The Annual Meeting of the American Educational Research Association, 12-16 Nisan, Atlanta. 29 Aralı 2012'de http://www.eric.ed.gov/ERICWebPortal/search/detailmini.jsp?_nfpb=true\&_\&ERICExtS earch_SearchValue_0=ED360702\&ERICExtSearch_SearchType_0=no\&accno=ED360702 adresinden alınmıştır.

Magaranes, L. M. (1993). Implementation of Total Quality Leadership (TQL) at Long Beach Naval Shipyard and Future Perspectives for Implementation by the Hellenic Naval Stations, (Yüksek Lisans Tezi), Naval Postgraduate School, ABD. 
Nicholls, M. T. (1991). Resistance to Total Quality Leadership Chance: An Evaluation of Individual Marine Response to TQL Principles and Changes, (Yüksek Lisans Tezi), Naval Postgraduate School, ABD.

Sığrı, Ü. (2006). Geleceğin Askeri Liderliğine Dair Değerlendirmeler, Güvenlik Stratejileri Dergisi, 2(3) 95-111.

Sniffin, R. A. (1994). Methods for Managing Quality (Student Guide), TQLO Publication Number 94-01, Department of the Navy Total Quality Leadership Office, Virginia, USA. 28 Aralık 2012'de http://www.dtic.mil/cgi-bin/GetTRDoc?AD=ADA255677 adresinden alınmıştır.

Şahin, A. ve Temizel, H. (2007).Bilgi Toplumunun Örgütsel Ve Yönetsel Yapılar Üzerine Etkileri Bağlamında Türk Kamu Yönetiminde Liderlik Anlayışı: Bir Anket Çalışması, S.Ü. Maliye Dergisi, 153, 179-194.

Şen, B. (2005). Türk Silahlı Kuvvetlerinde Toplam Kalite Yönetimi Çalışmaları, (Yüksek Lisans Tezi), Dumlupınar Üniversitesi Sosyal Bilimler Enstitüsü, Kütahya.

Taştekin, N. (2000). Implementation of Total Quality Leadership in the Turkish Army Academy, (Yüksek Lisans Tezi), Naval Postgraduate School, ABD.

Theodossiou, A. (1993). Assessment of the Implementation of Total Quality Leadership (TQL) on US Navy Operating Forces and Perspectives for Future Implementation by the Hellenic Navy, (Yüksek Lisans Tezi), Naval Postgraduate School, ABD.

Tikici, M., Demirel, E. T., ve Derin, N. (2005). Bilgi Toplumunda Toplam Kalite Liderliği: Elazığ Bankacılık ve Finans Sektörü Uygulaması, Fırat Üniversitesi Sosyal Bilimler Dergisi, 15(2), 229-245.

Ward, J. (1992). Department of Navy Total Quality Leadership Source Guide, TQLO Publication Number 92-01, Department of the Navy Total Quality Leadership Office, Virginia, USA. 27 Aralık 2012'de http://www.dtic.mil/cgi-bin/GetTRDoc?AD=ADA255677 adresinden alınmıştır.

White, M. A., ve Culbertston A. L. (1992). Recognizing, Awarding and Appraising people in a Total Quality Leadership Organization: The Navy Aviation Supply Office Model, TQLO Publication Number 92-04, Department of the Navy Total Quality Leadership Office, Virginia, USA. 28 Aralık 2012' de $h t t p: / / w w w . d t i c . m i l / d t i c / t r / f u l l t e x t / u 2 / a 275420 . p d f$ adresinden alınmıştır.

Yıldırım, Ş. (2006). Emniyet Teşkilatı Çalışanlarının Toplam Kalite Yönetimi Uygulamalarına Yönelik Değerlendirmesi İstanbul Emniyet Müdürlüğ̈̈ Örneği, (Yüksek Lisans Tezi), Sakarya Üniversitesi Sosyal Bilimler Enstitüsü, Sakarya.

Zel, U. (2006). Kişilik ve Liderlik, Nobel Yayın Dağıtım, İkinci Baskı, Ankara. 